\title{
FORTIFICATION IN THE SOUTH-EASTERN PART OF EUROPEAN RUSSIA AT THE END OF THE XVI - BEGINNING OF THE XVII CENTURIES
}

(C) 2019

Dubman Eduard Leibovich, doctor of historical sciences, professor of Russian History Department Samara National Research University (Samara, Russian Federation)

\begin{abstract}
The paper discusses the features of the Volga city fortresses (Samara, Saratov and Tsaritsyn) development at its initial stage in the second half of the 1580s by knyaz G.O. Zasekin. The task is to consider the process of their urban planning appearance and defensive structures development as well as the composition of the inhabitants at the end of the XVI - beginning of the XVII centuries. The source base of the study is archival and published narrative, acts and other sources. A wide range of studies have been used, mainly in recent decades. It is concluded that until the end of the Time of Troubles, the population of the Volga fortress cities consisted of service people and members of their families. The settlements performed both military and commercial functions on the Volga route, but in fact, all of them were fortresses. Their garrisons were mainly supplied by the sovereign «bread and money salary» and were not able to provide themselves through fishing and other activities. The events of the Time of Troubles contributed to a deep crisis in the life of the Volga cities, the death of Saratov and Tsaritsyn. It was only after the end of the Time of Troubles when their restoration took place and a new system of fortifications was created.

Keywords: Southeastern part of European Russia; Volga; Samara Tsaritsyn; Saratov; fortified cities; jails; Time of Troubles; governors; military garrisons; service people; archers; food supply; urban population; Kremlin-Detinets; settlements; Carmelite monks; Fedot Kotov; Holstein Embassy; Adam Olearius.
\end{abstract}

$* * *$

УДК 908

DOI 10.24411/2309-4370-2019-14210

Статья поступила в редакцию 26.07.2019

\section{САМАРСКИЙ ОБЩЕСТВЕННЫЙ ДЕЯТЕЛЬ И ДЕПУТАТ ГОСУДАРСТВЕННОЙ ДУМЫ РОССИЙСКОЙ ИМПЕРИИ В.А. ПЛЕМЯННИКОВ} (C) 2019

\author{
Елисеев Андрей Иванович, аспирант кафедры российской истории \\ Самарский национальный исследовательский университет имени академика С.П. Королёва \\ (2. Самара, Российская Федерация)
}

\begin{abstract}
Аннотация. В данной статье на основе анализа опубликованных и архивных документов, материалов периодической печати, воспоминаний современников рассмотрена общественно-политическая деятельность члена Самарской земской управы, одного из организаторов Самарского губернского и Бузулукского уездного комитетов конституционно-демократической партии, депутата Государственной Думы Российской империи первого созыва Василия Андреевича Племянникова. Прослежена работа В.А. Племянникова в земских учреждениях Самарской губернии и общероссийских земских съездах, в ходе которой он хорошо изучил положение дел в регионе, получил богатый опыт общественной деятельности и сформировал свои политические взгляды. Показаны его взаимоотношения с центральными органами власти и региональными общественными организациями. Годы первой русской революции стали вершиной его общественно-политической деятельности. В статье анализируется активное участие В.А. Племянникова в избирательной кампании по выборам в Государственную Думу и организация им местного отдела конституционно-демократической партии в Бузулукском уезде. Проведенная им большая агитационная работа и политический вес в губернии способствовали избранию Племянникова в депутаты Государственной Думы. Помимо реконструкции политической деятельности В.А. Племянникова в статье вводятся в научный оборот ранее неизвестные биографические данные.

Ключевые слова: Племянников Василий Андреевич; земские деятели; политическая биография; Государственная Дума Российской империи; Самарская губерния; Бузулукский уезд; конституционно-демократическая партия; депутаты; общественная деятельность; земские съезды; выборы в Государственную Думу; либералы.

В современной отечественной исторической науке наметился устойчивый интерес к изучению региональных политических деятелей. Внимание исследователей направлено на функционирование как определенных политических групп, так и их отдельных представителей. В связи с этим актуальным является изучение деятельности депутатов от Самарской губернии в Государственных Думах Российской империи. Рассмотрение данной проблемы позволит расширить представление о социально-политическом развитии региона, а также о взаимоотношении власти и общества. Целью данной статьи является рассмотрение общественной и политической деятельности В.А. Племянникова.

В исторической литературе представлена, в основном, информация о Племянникове как земском деятеле и депутате Государственной Думы Российской империи. Краткие биографические сведения опубликованы в дореволюционных справочных изданиях [1, с. 290; 2, c. 68; 3, с. 54], посвященных Государственной Думе, энциклопедии «Государственная дума Российской империи, 1906-1917» [4, с. 464], в «Энциклопедии Самарской области» [5, с. 183] и коллективной монографии «Самарское земство: опыт практической деятельности» [6, с. 95-96]. Некоторые сведения можно найти в работах, посвященных конституционно-демократической партии [7]. Отдельно общественно-политическая деятельность В.А. Племянникова не изучалась.
\end{abstract}


Василий Андреевич Племянников родился в 1845 году в Бузулукском уезде Самарской губернии в дворянской семье. Получил домашнее образование $[4$, с. 464]. Занимался сельским хозяйством в своем имении при деревне Красная Слободка [3, с. 54]. С 1871 года Племянников начал активно участвовать в общественной жизни, он регулярно избирался в Бузулукское уездное земское собрание [1, с. 290], а с 1874 года - и в губернское [8]. В 1894 году Племянников стал членом Самарской губернской земской управы [2, с. 68], а в январе 1896 года был избран ее председателем. Однако власти не утвердили Племянникова в этой должности. В петербургской газете «Неделя» 1896 года по этому поводу сообщалось, что Племянников в течение тридцати лет бессменно состоял уездным и губернским гласным, а также занимал должности председателя Бузулукской уездной земской управы, непременного члена уездного по крестьянским делам присутствия и кандидата в предводители дворянства. Трехлетняя служба его в управе, при крайне сложных условиях (управа в это время не имела третьего члена, а председатель управы сначала отвлекался от земских дел поручениями министерства финансов, а потом перешел на государственную службу) показала, что в лице Василия Андреевича губернская управа нашла дельного работника. Все были убеждены, что при выборах нового состава управы единственным серьезным кандидатом на должность председателя явится Племянников. И он действительно был избран председателем но послужить земству в этой должности ему не удалось [9, с. 771]. Как отмечалось в юбилейном докладе губернского земского собрания, период с 1895 по 1905 годы стал для самарского земства десятилетием самых многочисленных «неутверждений» земских служащих, причиной которых были конфликты земства и администрации. «Неутверждение» Племянникова в качестве председателя губернской земской управы, по признанию земцев, стало одной из наиболее резких форм проявлений недоверия администрации к земству $[10$, с. 46$]$.

В том же году В.А. Племянников выступил с инициативой, которая стала одной из попыток, предпринимаемых умеренными земскими деятелями по возобновлению легального единения земств. Василий Андреевич обратился к председателю Московской губернской земской управы Д.Н. Шипову с предложением организовать «общеполезное дело» на средства губернских земств в честь коронации Николая II [11, с. 54-55]. Несмотря на общее сочувствие данной идее земских деятелей, министр внутренних дел И.Л. Горемыкин отнесся к ней отрицательно, и предложение не было реализовано. Однако инициатива Племянникова подтолкнула Шипова предложить земцам устраивать ежегодные частные съезды для координации земской деятельности [7, с. 56].

Помимо выполнения земских обязанностей Василий Андреевич состоял членом самарского отделения Государственного дворянского поземельного банка, выбирался в губернское дворянское собрание, входил в попечительские советы учебных заведений, занимал должность почетного мирового судьи Бузулукского уезда, а также был членом губернского сельскохозяйственного общества.

Вплоть до 1902 года Племянников продолжал оставаться членом губернской земской управы, занимая нередко должность заступающего председателя. В управе он заведовал больничным и санитарным отделами [8]. А в 1902 году становится полноправным председателем губернской управы.

В том же году Василий Андреевич принимает участие в первом общеземском нелегальном съезде, который был инициирован председателем Московской губернской управы Д.Н. Шиповым. К 23 мая в Москву съехались представители большинства губернских управ, в числе которых был и В.А. Племянников [12, c. 12-13]. Съезд был связан с созданием комитетов о нуждах сельскохозяйственной промышленности, которые должны были помогать деятельности Особого совещания. Обсудив данный вопрос, участники съезда разработали и приняли программу мероприятий, которые требовались не только для выяснения, но и для удовлетворения нужд сельскохозяйственной промышленности. Положения программы включали в себя изменения в политических и социально-экономических сферах жизни страны [12, с. 603].

Позднее Племянников вошел в состав комитета о нуждах сельскохозяйственной промышленности, за время работы в котором зарекомендовал себя «не вполне благонадежным в политическом отношении» земцем [13, с. 358-359]. Как вспоминал предводитель самарского дворянства и один из лидеров самарских консерваторов А.Н. Наумов, Василий Андреевич не ладил с губернскими властями, «находясь в отношении к ним в состоянии "хронической" оппозиции» $[14$, с. 258$]$.

В 1905 году политизация различных сфер жизни в стране распространилась и на земство. В феврале 1905 года случился «чемодуровский инцидент». На очередной сессии губернского земства произошло столкновение между либералами и консерваторами. В местном обществе надеялись, что самарское земство, подобно коллегам из других губерний, выступит с заявлениями о необходимости решительных политических преобразований. Однако консерваторы во главе с председателем собрания Чемодуровым препятствовали обсуждению данного вопроса. 7 февраля после бурных прений часть гласных покинула заседание, и земское собрание было закрыто. В ответ на это либерал В.А. Племянников в центральных газетах опубликовал письмо протеста против действий Чемодурова [15, с. 66-67].

В мае того же года Василий Андреевич принял участие в коалиционном съезде земских деятелей, ставившем своей целью выработать «национальную петицию» на имя государя. На съезде он выступил с предложением о внесении в текст адреса всех пунктов ноябрьского земского съезда [12, с. 221-223, 233], на котором рассматривалась программа изменения государственного устройства и принятия конституции (Племянников также был делегатом того съезда). После длительных и бурных обсуждений съездом был принят проект «Адреса на Высочайшее имя», предложенный С.Н. Трубецким и содержавший призыв к немедленному созыву народных представителей [12, с. 618].

Манифест 17 октября 1905 года открыл дорогу для создания легальных политических партий. В октябре того же года состоялся первый (учредительный) съезд конституционно-демократической партии. В обстановке революционной смуты земства теряли значение важнейшей арены политических конфликтов: политическая борьба становилась уделом партий, союзов и общественных организаций. Земские гласные в зависимости от своих взглядов примыкали к определенным партиям [16, с. 15]. В декабре 1905 года в Самаре сформировался временный 
губернский комитет конституционно-демократической партии, куда помимо В.А. Племянникова вошли земцы Г.Н. Костромитинов, П.Л. Кузьмин и другие [15, с. 373]. 15 января 1906 года состоялся учредительный съезд Самарского отдела конституционнодемократической партии, Племянников вошел в состав избранного губернского комитета [17, с. 32]. Далее начался процесс образования местных партийных организаций в городах и селах губернии. Согласно донесению бузулукского исправника самарскому губернатору, в начале 1906 года в Бузулуке под председательством Василия Андреевича Племянникова образовался местный отдел партии Народной свободы в количестве 60 человек. Племянников ставил своей личной целью увеличение числа членов партии. Кадеты раздавали листки-воззвания к крестьянам, в которых говорилось о выборах в Думу, партиях, представительной монархии, конституции, учредительном собрании, правах народа, порядке правления, новом наделении землей, уменьшении податей, крестьянских правах, народном просвещении и народном кредите. Исправник отмечал, что ограничиваясь небольшими указаниями в своих программах, члены этой партии тайно вырабатывали более широкие преобразования. По результатам донесения в отношении Василия Племянникова даже было произведено негласное расследование [18, л. 175-175 об., 177].

Племянников как председатель Бузулукского отдела конституционно-демократической партии вел активную политическую агитацию. Так, по сообщению одного из полицейских надзирателей города Бузулука, 29 января 1906 года Племянников без разрешения собрал в своей квартире заседание и после него раздавал листки крестьянам. А местный мещанский староста Никитин, приходившийся родственником Племянникову, помогал ему распространять листки и набирать членов партии [18, л. 172]. В «Вестнике партии Народной свободы» в 1906 году отмечалось, что предвыборная кампания шла оживленно в Самаре и Бузулуке [19, с. 172]. В Бузулуке местные представители партии Племянников и Костромитинов с трудом добились от губернатора разрешения на собрания [20, с. 748$]$. А.Г. Елшин, один из членов губернского комитета партии кадетов, позднее вспоминал выступление В.А. Племянникова во время выборов в Думу. По мнению Елшина, благодаря своей популярности, влиянию и обдуманному выступлению, Племянникову удалось тогда «слить воедино разъединенные политические группы - партию Народной свободы и крестьянскую группу». Благодаря этому слиянию прогрессистам удалось сравнительно легко отразить натиск реакционных сил [8]. Плоды столь активной агитационной работы проявились в результатах выборов.

28 марта 1906 года на губернском избирательном собрании 124 выборщиками из 176 Племянников был избран в депутаты Государственной Думы [4, с. 464]. Василий Андреевич подошел к работе в представительном органе в статусе самого возрастного самарского депутата. Он был также одним из самых опытных общественно-политических деятелей губернии (наряду с Костромитиновым), ясно понимавшим положение дел в родном крае. Предводитель Самарского губернского дворянства А.Н. Наумов характеризовал Племянникова как опытного земского работника, хорошо знавшего свою губернию [14, с. 258].

В Государственной Думе Племянников вошел в состав конституционно-демократической фракции. В представительном органе Василий Андреевич работал в продовольственной комиссии, поддержал 9 депутатских запросов (в основном, касались действий полиции и местных властей), три раза выступал в прениях, подписал заявление 151-го члена Государственной Думы о гражданском равенстве [21, с. 100]. Дважды он высказывался при обсуждении ответного адреса на тронную речь императора. Василий Андреевич ратовал за сокращение прений по проекту ответного адреса, указывая, что в нем содержится просьба прекратить смертные казни, а поэтому промедление с ответным адресом могло стоить человеческих жизней. Его речь депутаты встретили бурными аплодисментами. В тот же день Племянников высказался по вопросу включения в проект ответного адреса предложения харьковского депутата Ковалевского, касающегося международных отношений. Племянников, обращая внимание на сложность рассматриваемого вопроса, предложил передать предложение в подготовительную комиссию [22, с. 205 , 223]. В следующий раз самарский депутат выступил в прениях 23 июня, когда обсуждался доклад бюджетной комиссии по проекту законопроекта на ассигнование 15 миллионов рублей для продовольственной помощи населению. Василий Андреевич указывал, что недоверие депутатов Думы к Министерству финансов не должно было стать препятствием к выдаче столь необходимой народу ссуды. В завершение своего выступления он сказал: «Мы волей или неволей, скрепя сердце, ну скажем, со скрежетом зубовным, должны поручить это министерству, которому мы вполне ничего не доверяем» [23, c. 1682]. Законопроект об ассигновании средств стал одним из двух, принятых первой Государственной Думой за время ее деятельности.

Государственная Дума первого созыва проработала недолго и в июле 1906 года была распущена. Непосредственно перед этим событием Племянникова вызвали на экстренное земское собрание в Самару. Впоследствии, как вспоминал депутат П.П. Крылов, Василий Андреевич очень сожалел о том, что не принял личного участия в составлении Выборгского воззвания, выражавшего протест против роспуска Думы. Он смог присоединиться к нему только заочно, телеграммой [8]. Возможно, благодаря этому его не постигла участь многих депутатов, подписавших Выборгское воззвание.

После работы в первой Государственной Думе Племянников неоднократно избирался в губернское земское собрание. Он также состоял членом губернского комитета партии Народной свободы. В последние годы своей жизни Василий Андреевич из-за болезни уже не принимал столь значимого участия в общественно-политической жизни страны.

До настоящего времени в исторической литературе не было представлено точных сведений о дате смерти В.А. Племянникова. В ходе изучения темы нам удалось выяснить, что в метрической книге церкви с. Карамзина Бузулукского уезда Самарской губернии сообщается о смерти Василия Андреевича Племянникова 23 ноября 1914 года [24, л. 44 об.-45]. Через два дня в помещении губернской земской управы в присутствии ее членов и губернского предводителя дворянства А.Н. Наумова была отслужена панихида [25]. 26 ноября того же года в газете «Волжское слово» появилась обширная статья, в которой воспоминаниями о Василии Андреевиче делились его коллеги 
по партии, Государственной думе и земству А.Г. Елшин, П.П. Крылов, В.Ф. Балясников и другие [8].

Таким образом, В.А. Племянников являлся значимой фигурой в политической жизни Самарской губернии конца XIX - начала XX вв. Его общественно-политическую деятельность можно условно разделить на три периода. Первый период (18711903 гг.) связан с его работой в уездном и губернском земских собраниях и в земской управе. В это время Племянников хорошо изучил губернию и стал одним из главных земских деятелей региона. С 1904 года начинается второй период его деятельности. Племянников принимает участие во всероссийских земских съездах, становится организатором Самарского и Бузулукского комитетов партии Народной свободы, ведет активную агитацию. В 1906 году он избирается депутатом Государственной Думы, что становится вершиной его политической карьеры. Уже после роспуска Думы Племянников сосредотачивает внимание на общественной деятельности в губернии, вплоть до своей смерти он продолжает работу в комитете конституционно-демократической партии, а также участвует в губернских земских собраниях.

\section{Список литературы:}

1. Члены Государственной думы (портреты и биографии): первый созыв, 1906-1911 / сост. М.М. Боиович. М.: Тип. И.Д. Сытина, 1906. 510 с.

2. Государственная Дума первого призыва: портреты, краткие биографии и характеристики депутатов. М.: Книгоизд-во «Возрождение», 1906. 126 с.

3. Члены 1-ой Государственной Думы: биографии, характеристики, политические взгляды, общественная деятельность, выборы и прочее: с портретами. М.: Тип. «Печать и гравюра», 1906. 79 с.

4. Государственная Дума Российской империи, 1906-1917: энциклопедия. М.: Российская политическая энциклопедия, 2008. 735 с.

5. Энциклопедия Самарской области: Н-Р. Самара: СамЛюксПринт, 2011. Т. 4. 313 с.

6. Самарское земство: опыт практической деятельности, 1865-1918 / под ред. П.С. Кабытова. Самара: Самарская Губернская Дума, 2009. 368 с.

7. Шеремеев Е.Е. Кадеты Поволжья в первой русской революции: 1905-1907 гг.: дис. ... канд. ист. наук. Самара, 2002. 245 с.

8. Волжское слово. Самара, 1914. 26 ноября.
9. Внутреннее обозрение // Вестник Европы. 1896. Т. 6, кн. 12. С. 764-783. $56 \mathrm{c}$.

10. Самарское земство, 1864-1914. Самара, 1914.

11. Белоконский И.П. Земское движение. М.: Задруга, 1914. 397 с.

12. Либеральное движение в России, 19021905 гг. М.: РОССПЭН, 2001. 646 с.

13. Кони А.Ф. На жизненном пути. Л.: Прибой, 1929. T. 5. 375 c.

14. Наумов А.Н. Из уцелевших воспоминаний. Кн. 1. Нью-Йорк: Изд. А.К. Наумовой и О.А. Кусевицкой, 1954. 377 с.

15. 1905 год в Самарском крае: материалы по истории РКП(б) и революционного движения / под ред. Н. Сперанского. Самара: Самарский губком РКП(б), $1925.788 \mathrm{c}$.

16. Леонов М.И. Политические течения в Самарском земстве в начале XX века // Самарский земский сборник. Самара: Изд-во «Самарский университет», 1995. C. 12-20.

17. Шеремеев Е.Е. Самарский «Сфинкс» при правительстве Колчака: А.К. Клафтон (1871-1920 гг.) биография на фоне эпохи. Самара: Изд-во Самар. муницип. ин-та упр., 2011. 338 с.

18. Центральный государственный архив Самарской области. Ф. 3. Оп. 233 сч. Д. 1941.

19. Самара // Вестник партии Народной свободы. СПб., 1906. № 3. С. 172-173.

20. Второй съезд партии Народной свободы Caмарской губернии // Вестник партии Народной свободы. СПб., 1906. № 11. С. 747-754.

21. Государственная Дума. Указатель к стенографическим отчетам. 1-й созыв. Сессия 1. Заседания 138 (27 апреля - 4 июля 1906 г.). СПб.: Государственная типография, $1907.316 \mathrm{c.}$

22. Стенографические отчеты Государственной Думы. 1906. 1-й созыв. Сессия 1. СПб.: Государственная типография, 1906. Т. 1.

23. Стенографические отчеты Государственной Думы. 1906. 1-й созыв. Сессия 1. СПб.: Государственная типография, 1906. Т. 2.

24. Государственный архив Оренбургской области. Ф. 389. Оп. 1. Д. 1961.

25. Голос Самары. 1914. 26 ноября.

\title{
SAMARA PUBLIC FIGURE AND DEPUTY OF THE STATE DUMA OF THE RUSSIAN EMPIRE V.A. PLEMYANNIKOV
}

(C) 2019

\author{
Eliseev Andrey Ivanovich, postgraduate student of Russian History Department \\ Samara National Research University (Samara, Russian Federation)
}

Abstract. The paper analyzes published and archival documents, periodical materials, and memoirs of contemporaries; it is devoted to the socio-political activities of the member of the Samara Zemstvo Council, one of the organizers of the Samara Provincial and Buzuluk Uyezd Committees of the Constitutional Democratic Party, deputy of the first State Duma of the Russian Empire, Vasily Andreevich Plemyannikov. The author examines the work of V.A. Plemyannikov in the Zemstvo institutions of the Samara province and All-Russian Zemstvo Congresses, where he studied the situation in the region, gained rich experience in social activities, and formed his political views. The paper also contains an overview of Plemyannikov's relations with Central authorities and regional public organizations. The author argues that the years of the first Russian revolution became the peak of Plemyannikov's social and political activity. The paper is focused on the active participation of V.A. Plemyannikov in the State Duma election campaign and the organization of the local branch of the Constitutional Democratic Party in Buzuluk Uyezd. Due to his active propaganda work and political significance in the province, Plemyannikov was elected to the State Duma. In addition to the reconstruction of political activity of V.A. Plemyannikov, the paper introduces previously unknown biographical data.

Keywords: Plemyannikov Vasily Andreevich; Zemstvo figures; political biography; State Duma of the Russian Empire; Samara province; Buzuluk Uyezd; Constitutional Democratic Party; deputies; public activities; Zemstvo Congresses; State Duma elections; liberals. 